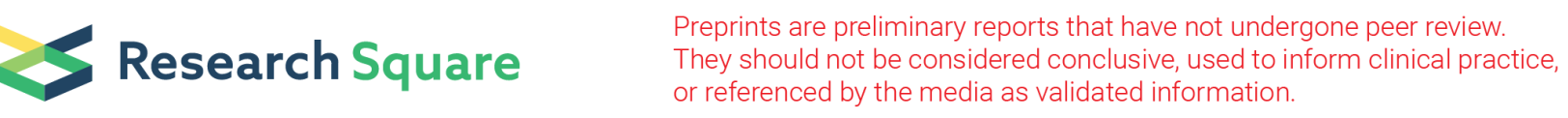

\title{
HIV-related Perceived Stigma and Associated Factors among Patients with HIV, Dilla, Ethiopia: Cross-Sectional Study
}

Yigrem Ali Chekole ( $\sim$ alyigrem@gmail.com )

\section{Research}

Keywords: Ethiopia, Perceived Stigma, HIV/AIDS

Posted Date: March 28th, 2020

DOI: https://doi.org/10.21203/rs.3.rs-19570/v1

License: (a) (i) This work is licensed under a Creative Commons Attribution 4.0 International License.

Read Full License

Version of Record: A version of this preprint was published at Annals of Medicine and Surgery on October 1st, 2021. See the published version at https://doi.org/10.1016/j.amsu.2021.102921. 


\section{Abstract}

\section{Background}

Understanding HIV-related perceived stigma has importance in improving quality of patients and provides a better tackling of HIV stigma.

Objective

The aim of the study was to assess the prevalence and associated factors of perceived stigma among Patients with HIV attending clinic at Dilla University Referral Hospital.

Method

In this Institution based cross-sectional study, a 10-item perceived HIV stigma scale was used to assess HIV-related perceived stigma. Oslo social support scale was used to assess social support related factors. Bivariate and multivariate binary logistic analysis were done to identify associated factors to HIV-related perceived stigma

Results

The prevalence of HIV-related perceived stigma by using perceived HIV stigma scale among Patients with living HIV was $42.7 \%$. Patients who are age groups $25-30$ years ( $A O R=2.8,95 \% \mathrm{Cl}$ : $5.72-11.5$ ), age groups 31-39 years $(A O R=1.11,95 \% \mathrm{Cl}: 1.26,4.65)$, Females (AOR= 2.4, 95\% Cl: 1.28-4.33), divorced marital status (AOR= 8.9, 95\% Cl: 3.52-10.61), widowed marital status (AOR=3.0, 95\% Cl: 2.74-7.60), Primary educational status (AOR=7.5, 95\% Cl: 3.45-9.74) and Study participants those who use alcohol (AOR=1.0 95\% Cl: 1.57-2.11) were more likely to have HIV-related perceived stigma.

Conclusion

This calls a holistic approach for the prevention and intervention of HIV-related perceived stigma. Emphasis should also be given for HIV-related perceived stigma.

\section{Introduction}

HIV-related perceived stigma remains pervasive and affects people with HIV the right to fully participate in their communities, affecting all aspects of people's lives, including access to treatment and care, and access to work Negative impact of HIV-related stigma (1) poor HIV outcome(2). People living with HIV may feel shame and fear of discrimination (3).

Perceived stigma my lead to a series of consequence's such as non-disclosure of HIV infection seclusion, depressive symptoms, and suicidal ideation and attempt(4,5). Due to this effect, PLWH have to cope both with the manifestations of the disease, complex treatment regimen and societal stigma at the same time 
$(6,7)$. HIV/AIDS related stigma and discrimination can be directed at infected people as well as their Friends, families, care takers and others $(8,9)$

Perceived stigma greatly affect the quality of life PLWH, their family members and the health care providers who works with them(10) and cause serious care limitation(11). stigma can also cause serious social and psychological damage and significantly increases loneliness, depression, anxiety, nondisclosure of HIV status and overall poor health outcomes $(12,13)$.

Sub Saharan Africa contributed 76\%(29 million) of the total HIV infected people(14). In Ethiopia the adult prevalence rate is estimated at $2.4 \%$ and the incidence rate is $0.29 \%(15,16,17)$

A recent systematic review found that over the last decade, evidence -based effective programming to reduce stigmatizing and discrimination attitude has expanded substantially (18). However almost no country has prioritized activities to reduce or eliminate them in their national plans or program (19). People who experience stigma report a range of negative effects including loss of income or job, Isolation from communities and inability to participate as a productive member of society $(20,21,22)$.

Globally $30 \%-80 \%$ of people living with HIV experience stigma during their life time (23). Study under taken among North Bengal medical college attending ART center revealed that $25.8 \%$ had perceived stigma(24). The study in Iran among women living with HIV reveals among PLWH had 69.7\%(25).

A study in Chennai substantiated the perceived stigma was $26 \%$ of the PLWH had actually experienced stigma(26). Other study reveal the prevalence of perceived stigma among people living with HIV attending ART clinic at university of Port Harcourt Teaching Hospital, Nigeria is $59.9 \%(27)$. A quantitative descriptive and cross sectional study in Ethiopia, Addis Ababa were non adherent and adherent to ART medication $36.2 \%$ and $10 \%$ perceived stigma respectively (28).

\section{Methods}

\section{Study Design and Setup}

An institutional based cross sectional study was conducted at Dilla University Referral Hospital AntiRetroviral clinic from April- May 2019. Dilla University Referral Hospital is found in Dilla Town (the capital of Gedeo Zone) Southern National's Nationalities and People Region and away $360 \mathrm{~km}$ from Addis Ababa, the capital city of Ethiopia. Patients receiving inpatient treatment and critically ill patients with difficulty of communication were excluded.

\section{Sample Size Determination And Technique}

It was determined by Level of significance (0.05), Power (0.50) with $z=95 \%$ confidence internal and the value of " $p$ " ( $p$ = proportion of prevalence) was taken as prevalence of perceived stigma among People Living with HIV which was found to be $61.1 \%$ (done in Jimma town, Ethiopia)(29). Then by adding $10 \%$ of 
non-respondents then, total sample size for this study is 403 . The study also used systematic random sampling technique from to select study subjects.

\section{Data Collection And Instruments}

The instruments had included Socio-Demographic characteristic which mainly focuses on age, sex, education, occupation, marital status, religious view of the study participants, and others. Oslo item 3 social support scales which is 3-item questionnaire and HIV stigma index validation survey were used. The outcome variable, HIV-related perceived stigma felt by HIV patients, was collected by 10 -item perceived HIV stigma scale that consisted of four-point Likert scale questions ( 1 = strongly disagree, $2=$ disagree, 3 = agree 4 = strongly agree) of their HIV status.

\section{Data Processing and Analysis}

The coded Data was checked, cleaned by entering into epi.info version 7.1 and then exported into Statistical Package for the Social Sciences (SPSS window version 20).

The Descriptive summary using frequencies, percentage and median were used to present study results. Both bivariable and multivariable binary logistic regression were computed to identify factors associated with HIV-related perceived stigma candidates for multivariable regression to control possible confounders. In the final model, variables with p-values of $<0.05$ were considered as having a statistically significant association with alcohol use at a corresponding $95 \% \mathrm{Cl}$.

\section{Result}

\section{Socio-Demographic Characteristics}

Most of the study subjects $206(51.1 \%)$ participants were females. $135(33.5 \%)$ respondents were at the age of $>39$ years, $206(51.1 \%)$ were married and 193 (47.9\%) respondents were orthodox in religion. Concerning ethnicity, 193 (47.6\%) and 112(27.8\%) of them were from Oromo and Gedeo ethnic group, respectively. The majority $182(45.2 \%)$ respondents had secondary school education, 124 (30.8\%) participants were government employee. Majority of the total respondents 161 (40.0\%) of them were live with their children 159 (39.5\%) were have poor social support and $244(60.5 \%)$ were have strong social support more than half of the respondents 223 (55.3\%) were use substance and 192 (47.6\%) were second stage of HIV. 
Table 1

Socio-Demographic characteristics of study participant in ART clinic, DURH, 2019

\begin{tabular}{|c|c|c|c|}
\hline \multicolumn{2}{|l|}{ Variable } & \multirow{2}{*}{$\begin{array}{l}\text { Frequency } \\
30\end{array}$} & \multirow{2}{*}{$\begin{array}{l}\text { Percentage (\%) } \\
8.7\end{array}$} \\
\hline Age & $18-24$ & & \\
\hline & $25-30$ & 124 & 30.8 \\
\hline & $31-38$ & 130 & 32.3 \\
\hline & $>39$ & 135 & 33.5 \\
\hline \multirow[t]{2}{*}{ Sex } & Male & 197 & 48.9 \\
\hline & Female & 206 & 51.1 \\
\hline \multirow[t]{4}{*}{ Marital status } & Single & 102 & 25.3 \\
\hline & Married & 206 & 51.1 \\
\hline & Divorced & 56 & 13.9 \\
\hline & Widowed & 39 & 9.7 \\
\hline \multirow[t]{4}{*}{ Religion } & Orthodox & 182 & 45.2 \\
\hline & Protestant & 123 & 30.2 \\
\hline & Muslim & 90 & 23.3 \\
\hline & Catholic & 8 & 2.0 \\
\hline \multirow[t]{4}{*}{ Ethnicity } & Gedeo & 133 & 33.0 \\
\hline & Oromo & 150 & 37.2 \\
\hline & Amara & 85 & 21.1 \\
\hline & Other ${ }^{A}$ & 14 & 3.5 \\
\hline \multirow[t]{4}{*}{ Educational status } & Can't read and write & 8 & 2.0 \\
\hline & Primary education & 34 & 8.4 \\
\hline & Secondary education & 182 & 45.2 \\
\hline & Higher education & 179 & 44.4 \\
\hline \multirow[t]{3}{*}{ Occupation } & Un employee & 58 & 14.4 \\
\hline & Governmental employee & 130 & 32.3 \\
\hline & Retire & 22 & 5.5 \\
\hline
\end{tabular}

Other $^{\mathrm{A}}=$ Silte, Tigre, Gurage, Other $^{\mathrm{B}}=$ farmer, daily labor 


\begin{tabular}{|c|c|c|c|}
\hline \multicolumn{2}{|l|}{ Variable } & \multirow{2}{*}{$\begin{array}{l}\text { Frequency } \\
103\end{array}$} & \multirow{2}{*}{$\begin{array}{l}\text { Percentage (\%) } \\
25.6\end{array}$} \\
\hline & Business man & & \\
\hline & Student & 34 & 8.4 \\
\hline & House wife & 47 & 11.7 \\
\hline & Other ${ }^{B}$ & 9 & 2.2 \\
\hline \multirow[t]{4}{*}{ Income } & $>1000$ & 73 & 18.1 \\
\hline & $1000-2500$ & 87 & 21.6 \\
\hline & $2500-4000$ & 115 & 28.5 \\
\hline & $<4000$ & 128 & 31.8 \\
\hline \multirow[t]{4}{*}{ Living status } & With family & 102 & 25.3 \\
\hline & Alone & 117 & 28.8 \\
\hline & With relative & 26 & 5.7 \\
\hline & With children & 162 & 40.2 \\
\hline
\end{tabular}

\section{Prevalence of HIV-related Perceived Stigma among people living with HIV}

The overall prevalence of Perceived Stigma was found to be 169 (42.7\%).

\section{Factors associated with HIV-related Perceived Stigma among people living with HIV}

In Bivariate analyses, age, sex, marital status, occupation status, ethnicity, educational status, income, living status, HIV stage, substance use, social support and living status were analyzed. Multivariate logistic regression was also used to analyze associations between variables which have $p$ value of $<0.2$ in Bivariate logistic regression. After adjusting for possible covariates, age, sex, marital status, ethnicity, educational status, occupational, living status, HIV stage was significantly associated with HIV-related perceived stigma among patients living with HIV with $p$-value $<0.05$.

Age groups $25-30$ years were 2.8 times more likely to have perceived stigma as compare to age $18-24$. $(\mathrm{AOR}=2.8,95 \% \mathrm{Cl}: 5.72-11.5)$. 
Age groups 31-39 years were 1.1 times more likely to have perceived stigma as compare to age 18-24. $(\mathrm{AOR}=1.11,95 \% \mathrm{Cl}: 1.26,4.65)$

Females were 2.36 times more likely to have perceived stigma as compared to males ( $A O R=2.36,95 \% \mathrm{Cl}$ : $1.28-4.33)$.

Study participants those had divorced marital status were 8.93 times more likely to have perceived stigma as compared to single (AOR $=8.93,95 \% \mathrm{Cl}$ : $3.52-10.61)$.

Study participants those had widowed marital status were 2.99 times more likely to have perceived stigma as compared to single $(\mathrm{AOR}=2.99,95 \% \mathrm{Cl}: 2.74-7.60)$.

Primary educational status 7.5 times more likely to develop perceived stigma as compared to participants who can't read and write (AOR $=7.5,95 \% \mathrm{Cl}: 3.45-9.74)$.

Study participants those who use alcohol were 1.01 times more likely to have perceived stigma as compared to khat $(\mathrm{AOR}=1.0195 \% \mathrm{Cl}: 1.57-2.11)$. 
Table 2

Bivariate and Multivariate analysis of factors associated with HIV-related Perceived Stigma 2019.

\begin{tabular}{|c|c|c|c|c|c|}
\hline \multirow[t]{2}{*}{ Variables } & & \multicolumn{2}{|c|}{$\begin{array}{l}\text { Perceived } \\
\text { stigma }\end{array}$} & \multirow[t]{2}{*}{$\operatorname{coR}(95 \% \mathrm{Cl})$} & \multirow[t]{2}{*}{$\mathrm{AOR}(95 \% \mathrm{Cl})$} \\
\hline & & No & Yes & & \\
\hline \multirow[t]{4}{*}{ Age $(n=395)$} & $18-24$ & 11 & 3 & 1 & 1 \\
\hline & $25-30$ & 61 & 63 & $3.78(1.0-4.23)$ & $\begin{array}{l}2.88(5.72- \\
11.5)^{\star \star}\end{array}$ \\
\hline & $31-39$ & 86 & 44 & $\begin{array}{l}1.87(0.50- \\
7.07)\end{array}$ & $\begin{array}{l}1.11(1.26- \\
4.65)^{\star \star}\end{array}$ \\
\hline & $>39$ & 73 & 62 & $\begin{array}{l}3.11(0.83- \\
11.66)\end{array}$ & $\begin{array}{l}1.97(0.457- \\
8.54)\end{array}$ \\
\hline \multirow[t]{2}{*}{$\operatorname{Sex}(n=395)$} & Male & 115 & 82 & 1 & 1 \\
\hline & Female & 116 & 90 & $\begin{array}{l}1.08(0.73- \\
1.61)\end{array}$ & $\begin{array}{l}2.36(1.28- \\
4.33)^{\star \star \star}\end{array}$ \\
\hline \multirow{4}{*}{$\begin{array}{l}\text { Marital status }(n= \\
395) \\
\text { Widowed }\end{array}$} & Single & 68 & 34 & 1 & 1 \\
\hline & Married & 124 & 82 & $\begin{array}{l}1.32(0.80- \\
2.18)\end{array}$ & $1.55(0.74-2.54)$ \\
\hline & Divorced & 19 & 37 & $\begin{array}{l}3.90(1.95- \\
7.76)\end{array}$ & $\begin{array}{l}8.93(3.52- \\
10.61)^{\star * *}\end{array}$ \\
\hline & Widowed & 20 & 19 & $\begin{array}{l}1.90(0.9- \\
4.03)\end{array}$ & $\begin{array}{l}2.99(2.74- \\
7.60)^{\star \star}\end{array}$ \\
\hline \multirow[t]{4}{*}{$\begin{array}{l}\text { Educational status }(\mathrm{n}= \\
\text { 395) }\end{array}$} & $\begin{array}{l}\text { Can't read and } \\
\text { write }\end{array}$ & 4 & 4 & 1 & 1 \\
\hline & $\begin{array}{l}\text { Primary } \\
\text { education }\end{array}$ & 8 & 26 & $\begin{array}{l}3.25(0.66- \\
16.04)\end{array}$ & $\begin{array}{l}7.50(3.45- \\
9.74)^{\star \star \star}\end{array}$ \\
\hline & $\begin{array}{l}\text { Secondary } \\
\text { education }\end{array}$ & 114 & 68 & $\begin{array}{l}0.60(0.14- \\
2.46)\end{array}$ & $\begin{array}{l}6.11(0.409- \\
9.258)\end{array}$ \\
\hline & Higher education & 105 & 74 & $\begin{array}{l}0.71(0.17- \\
2.91)\end{array}$ & $\begin{array}{l}8.39(0.54- \\
12.33)\end{array}$ \\
\hline \multirow{3}{*}{$\begin{array}{l}\text { Substance use }(n= \\
395)\end{array}$} & Khat & 56 & 27 & 1 & 1 \\
\hline & Alcohol & 70 & 79 & $\begin{array}{l}1.61(1.04- \\
2.50)\end{array}$ & $1.01(1.57-2.11)^{*}$ \\
\hline & Cigarette & 2 & 0 & $\begin{array}{l}0.54(0.30- \\
0.96)\end{array}$ & $0.18(0.07-1.46)$ \\
\hline HIV stage $(n=395)$ & Stage 1 & 104 & 92 & 1 & 1 \\
\hline
\end{tabular}




\begin{tabular}{lllll}
\hline Stage 2 & 93 & 76 & $0.92(0.61-1.4)$ & $1.48(0.870-$ \\
& & & & $2.53)$ \\
Stage 3 & 34 & 4 & $\begin{array}{l}0.13(0.05- \\
0.39)\end{array}$ & $0.14(0.041-1.51)$ \\
& & & &
\end{tabular}

$P^{*}<0.05, P * *<0.01, P * * *<0.001$

\section{Discussion}

The study has tried to determine the prevalence of HIV-related perceived stigma and associated factors among people living with HIV attending Ante-retroviral clinic at Dilla University Referral Hospital thus the prevalence of HIV-related perceived stigma was found to be $42.7 \%$.

According to this study the prevalence of HIV-related perceived stigma and associated factors among people living with HIV attending Ante-retroviral clinic was lower than the study conducted in Jimma Town was $61.1 \%$ (29) and in Nigeria 59.9\%(27). The difference might be due to the socio-economical status of the study setting, sample size of the study, the influence of cultural and religious norms of the society.

The study is higher than A study conducted in Addis Ababa (36.2\%) and 10\%(28) The reason for the noted difference might be attitude of the society in the study area, cultural variation, and educational status of the society and norms of the society.

Age groups 25-31 and 31-39 years were 2.8 and 1.1 times more likely to have HIV-related perceived stigma as compare to age 18-24 years respectively(29). The reason noted that this level of age is high productive level; in terms of work, family and social relationship within the society accordingly and expect more role at this level of age.

Females were 2.4 times more likely to have HIV-related perceived stigma as compare to males (25). The hormonal difference which may play important and are more vulnerable for gender discrimination, and neglect. They may suffer more perceived stigmas because the community views them as having been promiscuous at least once in their lifetime when they are infected with HIV.

Study participants those had divorced marital status were 8.9 times more likely to have HIV-related perceived stigma as compare to singles (25). This might be due to infected with this HIV might cause divorcing of study participants. Study participants those had widowed marital status were 3.0 times more likely to have perceived stigma as compare to singles (25). This is might be due to decreasing of family and friend support with being HIV infected and widowed due its morbidity and mortality.

Primary educational status 7.5 times more likely to develop HIV-related perceived stigma as compare to participants who can't read and write the study participants (25).it might be little awareness of having HIV makes them stigmatize, cultural influence, norm of the society and educational status. 
Study participants those who use alcohol were 1.0 times more likely to have HIV-related perceived stigma as compare to khat (25). This might be that drinking alcohol and khat chewing are interrelated. Therefore, this study gives additional evidence for planning appropriate intervention in drinking alcohol and khat chewing HIV infected patient who are on ART at clinic.

\section{Conclusion}

The prevalence of HIV-related perceived stigma is high in the study among Patients with living HIV. Of great concern is the large numbers of patients with living HIV who have HIV-related perceived stigma remain undetected in the study area.

Being female, Patients who are age groups 25-30 years, age groups 31-39 years, divorced marital status, widowed marital status, Primary educational status and Study participants those who use alcohol were more likely to have HIV-related perceived stigma. Therefore; this calls a holistic approach for the prevention and intervention of HIV-related perceived stigma. Emphasis should also be given for HIVrelated perceived stigma.

\section{Limitation of the Study}

Participants were enrolled from government ART clinics which might not be representative for patients who do not attend government ART.

The cross-sectional nature of the study design might not show the cause and effect relationships between HIV-related perceived stigma and other variables

\section{Abbreviations}

AOR: adjusted odd ratio; Cl: confidence interval; COR: crude odd ratio; DURH: Dilla University Referral Hospital; ETB: Ethiopian Birr; SD: standard, HIV : Human immune Viruses, WHO: World Health Organization. PLWH: people living with HIV, ART: Antiretroviral treatment

\section{Declarations}

\section{Ethics approval and consent to participate}

The study was ethically approval by the Institutional Review Board (IRB) of Dilla University. Formal permission was also obtained from Hospital Director and finally written consent was obtained from each participant during data collection. All participants were well informed about the aims and purpose of the study. The right was given to the study participants to refuse or withdraw from participation at any time during data collection without loss of any entitlement.

\section{Consent for publication:}


Not applicable

\section{Availability of data and material}

The data used to support the findings of this study are included within the article.

Conflicts of Interest: The author declares that he has no conflicts of interest.

\section{Funding:}

Not applicable

\section{Author Contribution}

YA conceived the research question, participated in the proposal development, data collection, analysis, interpretation, critically reviewed and approved the manuscript.

\section{Acknowledgement}

The author appreciates and thanks the respective study institution for their help and the study participants for their cooperation in providing all necessary information.

\section{Authors' information (optional)}

${ }^{1 *}$ Department of Psychiatry, college of health science and medicine, Dilla University, Dilla, Ethiopia

\section{References}

1. Friedland BA, Sprague L, Nyblade L, Baral SD, Pulerwitz J, Gottert A, et al. Measuring intersecting stigma among key populations living with HIV: implementing the people living with HIV Stigma Index 2.0. Journal of the International AIDS Society. 2018;21(Suppl Suppl 5).

2. Dlamini PS WD, Makoae LN, Chirwa M, Kohi TW, Greeff M, Naidoo J, Mullan J, Uys LR, Holzemer WL. HIV Stigma and Missed Medications in HIV-Positive People in Five African Countries.AIDS Patient Care and STDs. 2009;23.

3. Li L, Lin C, Wu Z, Wu S, Rotheram-Borus MJ, Detels R, et al. Stigmatization and shame: consequences of caring for HIV/AIDS patients in China. AIDS care. 2007;19(2):258-63.

4. Thanh DC, Moland KM, Fylkesnes K. Persisting stigma reduces the utilisation of HIV-related care and support services in Viet Nam. BMC health services research. 2012;12(1):428.

5. Lifson AR, Demissie W, Tadesse A, Ketema K, May R, Yakob B, et al. HIV/AIDS stigma-associated attitudes in a rural Ethiopian community: characteristics, correlation with HIV knowledge and other factors, and implications for community intervention. BMC International Health and Human Rights. 2012;12(1):6. 
6. Alonzo AA, Reynolds NR. Stigma, HIV and AIDS: An exploration and elaboration of a stigma trajectory. Social science \& medicine. 1995;41(3):303-15.

7. Bongaarts J. Global trends in AIDS mortality. Population and Development Review. 1996:21-45.

8. Bunting SM. Sources of stigma associated with women with HIV. Advances in Nursing Science. 1996;19(2):64-73.

9. Danziger R. The social impact of HIV/AIDS in developing countries. Social science \& medicine. 1994;39(7):905-17.

10. Pourmarzi D, Khoramirad A, Gaeeni M. Perceived Stigma in People Living With HIV in Qom. Journal of family \& reproductive health. 2017;11(4):202.

11. Katz IT, Ryu AE, Onuegbu AG, Psaros C, Weiser SD, Bangsberg DR, et al. Impact of HIV-related stigma on treatment adherence: systematic review and meta-synthesis. Journal of the International AIDS Society. 2013;16:18640.

12. Mukolo A, Torres I, Bechtel RM, Sidat M, Vergara AE. Consensus on context-specific strategies for reducing the stigma of human immunodeficiency virus/acquired immunodeficiency syndrome in Zambe' zia Province, Mozambique. SAHARA-J: Journal of Social Aspects of HIV/AIDS. 2013;10(34):119-30.

13. Rao D, Chen W-T, Pearson CR, Simoni JM, Fredriksen-Goldsen K, Nelson K, et al. Social support mediates the relationship between HIV stigma and depression/quality of life among people living with HIV in Beijing, China. International journal of STD \& AIDS. 2012;23(7):481-4.

14. Wang H, Wolock TM, Carter A, Nguyen G, Kyu HH, Gakidou E, et al. Estimates of global, regional, and national incidence, prevalence, and mortality of HIV, 1980-2015: the Global Burden of Disease Study 2015. The lancet HIV. 2016;3(8):e361-e87.

15. Mbonu NC, van den Borne B, De Vries NK. Stigma of people with HIV/AIDS in Sub-Saharan Africa: a literature review. Journal of tropical medicine. 2009;2009.

16. Ortblad KF, Lozano R, Murray CJ. The burden of HIV: insights from the Global Burden of Disease Study 2010. AIDS (London, England). 2013;27(13):2003.

17. Luiz B. Can [conditional] cash transfers contribute to HIV prevention for girls. geneva: UnESCO, gender Equality, HIV and Education; 2012.

18. Fido NN, Aman M, Brihnu Z. HIV stigma and associated factors among antiretroviral treatment clients in Jimma town, Southwest Ethiopia. HIV/AIDS (Auckland, NZ). 2016;8:183.

19. Goldin CS. Stigmatization and AIDS: Critical issues in public health. Social science \& medicine. 1994;39(9):1359-66.

20. Corrigan PW. Mental health stigma as social attribution: Implications for research methods and attitude change. Clinical psychology: science and practice. 2000;7(1):48-67.

21. Organization IL. Recommendation Concerning HIV and AIDS and the World of Work, 2010 (No. 200). ILO Geneva; 2010. 
22. Sorsdahl KR, Mall S, Stein DJ, Joska JA. The prevalence and predictors of stigma amongst people living with HIV/AIDS in the Western Province. AIDS care. 2011;23(6):680-5.

23. Datta S, Bhattacherjee S, SherPa PL, Banik S. Perceived HIV related stigma among patients attending art center of a tertiary care center in rural West Bengal, India. Journal of clinical and diagnostic research: JCDR. 2016;10(10):VC09.

24. Zarei $\mathrm{N}$, Joulaei $\mathrm{H}$, Fararouei M. Perceived stigma and quality of life among women living with HIV/AIDS. Women's Health. 2016;4:e34535.

25. Thomas B, Rehman F, Suryanarayanan D, Josephine K, Dilip M, Dorairaj V, et al. How stigmatizing is stigma in the life of people living with HIV: a study on HIV positive individuals from Chennai, South India. AIDS care. 2005;17(7):795-801.

26. Kanu CT, Maduka O, Okeafor CU. Perceived stigma and highly active antiretroviral treatment adherence among persons living with HIV/AIDS in the University of Port Harcourt Teaching Hospital. Orient Journal of Medicine. 2017;29(1-2):40-7.

27. Feyissa GT, Abebe L, Girma E, Woldie M. Stigma and discrimination against people living with HIV by healthcare providers, Southwest Ethiopia. BMC Public Health. 2012;12(1):522.

28. Caliari JdS, Teles SA, Reis RK, Gir E. Factors related to the perceived stigmatization of people living with HIV. Revista da Escola de Enfermagem da USP. 2017;51.

29. Li Z, Morano JP, Khoshnood K, Hsieh E, Sheng Y. HIV-related stigma among people living with HIV/AIDS in rural Central China. BMC health services research. 2018;18(1):453. 